\title{
DERAJAT DESENTRALISASI FISKAL DAN KEMANDIRIAN DAERAH KOTAMADYA METRO DAN LAMPUNG TIMUR
}

\author{
Rita Rahmawati \\ IBI Darmajaya Lampung \\ e-mail: ritarahmawati1777@yahoo.co.id
}

\begin{abstract}
ABSTRAK
Part of Regional Otonomy in finance is giving local government to arrange regional receipt to purchase expenses bugget. Government genuine Receipt is one regional receipt that shows how stronger local goverment finance can handled all the expenditure, not only depend on Central Government. Metro and Lampung Timur same with another local government in Indonesia, wants the higher regional otonomy espescialy in finance. The higher decentralization indicate higher ability on local government to fulfill all expenditure. In can be analized from share of Government Genuine Receipt and Tax and non Tax Share compare Total Regional Receipt and Total Regional Expenditure. Higher fiscal Desentralization needed by Metro and Lampung Timur to get higher Regional otonomy.

Keywords: Regional Otonomy, Desentralization, Government Genuine Receipt and Tax and non Tax Share compare Total Regional Receipt and Total Regional Expenditure
\end{abstract}

\section{PENDAHULUAN}

Otonomi daerah di Indonesia pada dasarnya adalah kegiatan pemerintah daerahuntukmengatur dan mengurus sendiri urusan pemerintahan dan kepentingan masyarakat setempat sesuai dengan peraturan perundang-undangan. Dijelaskan Dalam UU No.32 Tahun 2004 bahwa otonomi daerah menggunakan prinsip otonomi seluas-luasnya, otonomi nyata dan bertanggungjawab.

Prinsip otonomi nyata adalah suatu prinsip yang menegaskan bahwa urusan pemerintahan dilaksanakan berdasarkan tugas, wewenang dan kewajiban yang senyatanya telah ada dan berpotensi untuk tumbuh, hidup, dan berkembang sesuai dengan potensi dan kekhasan daerah.

Otonomi yang bertanggung jawab adalah otonomi yang dalam penyelenggaraannya harus benar-benar sejalan dengan tujuan dan maksud pemberian otonomi yang pada dasarnya untuk memberdayakan daerah termasuk meningkatkan kesejahteraan rakyat sebagai bagian utama dari tujuan nasional.

Pelaksanaan otonomi daerah di bidang keuang daerah adalah dengan memberi kewenangan daerah untuk menggali potensi pendapatan asli daerah sebagai komponen utama dalam pembentuk penerimaan daerah dan digunakan untuk membiayai pengeluaran daerah. Kemampuan daerah untuk membiayai kebutuhan daerah tersebut akan menunjukkan tingkat kemandirian daerah dari ketergantungannya kepada bantuan pemerintah pusat.

Kotamadya Metro dan Kabupaten Lampung Timur seperti daerah-daerah lain di Indonesia juga melaksanakan otonomi daerah seperti yang 
ditetapkan Pemerintah Pusat. Berbagai potensi yang dimiliki Kotamadya Metro dan Kabupaten Lampung Timur untuk melaksanakan otonomi daerah terutama dalam bidang keuangan daerah dapat dianalisa dengan peran Pendapatan Asli daerah dan Bagi hasil Pajak/Bukan Pajak terhadap Total Penerimaan Daerah dan Total Pengeluaran Daerah.

\section{REVIEW LITERATUR DAN HIPOTESIS}

Kegiatan Pemerintah (Suparmoko ,1986) dalam perekonomian sangat diperlukan dapat digolongkan menjadi 4 golongan:

1. Kegiatan dalam mengalokasikan faktorfaktor produksi maupun barang dan/atau jasa-jasa untuk memuaskan kebutuhan masyarakat

2. Kegiatan dalam mengadakan redistribusi pendapatan atau mentransfer pendapatan

3. Kegiatan menstabilkan perekonomian

4. Kegiatan mempercepat pertumbuhan ekonomi

Pelaksanaan Otonomi daerah diatur dalam Beberapa aturan perundang-undangan yang berhubungan dengan pelaksanaan Otonomi Daerah:

1. Undang-Undang No. 5 Tahun 1974 tentang Pokok-pokok Pemerintahan Daerah

2. Undang-Undang No. 22 Tahun 1999 tentang Pemerintahan Daerah

3. Undang-Undang No. 25 Tahun 1999 tentang Perimbangan Keuangan Antara Pemerintah Pusat dan Daerah

4. Undang-Undang No. 32 Tahun 2004 tentang Pemerintahan Daerah

5. Undang-Undang No. 33 Tahun 2004 tentang Perimbangan Keuangan Antara Pemerintah Pusat dan Pemerintahan Daerah

6. Perpu No. 3 Tahun 2005 tentang Perubahan atas Undang-Undang No. 32 Tahun 2004 tentang Pemerintahan Daerah
7. Undang-Undang No. 12 Tahun 2008 tentang Perubahan Kedua atas UndangUndang No. 32 Tahun 2004 tentang Pemerintahan Daerah

Pengaturan pemerintahan di daerah dalam Pokok-Pokok Pemerintahan di daerah di atur dengan UU No. 5/1974, dalam Pasal 13 ayat 1 menyatakan bahwa Pengertian pemerintah daerah adalah kepala daerah dan DPRD. Pasal 77 tercantum bahwa, Kepala Daerah dalam hal ini bupati dan wali kotamadya, sekarang walikota merupakan perwakilam pemerintah tingkat yang lebih tinggi (pemerintah pusat atau pemerintah propinsi) di daerah.

Perkembangan selanjutnya, hubungan pemerintah daerah dan pemerintah pusat ditetapkan dalam UU No. 22/1999, yang disempurnakan lagi dengan UU No. 32/2004. Pengertian Pemerintah Daerah mencakup kepala daerah beserta perangkat daerah lainnnya . Kepala Daerah bertanggungjawab kepada DPRD. Kewenangan dalam bidang keuangan daerah yang dimiliki daeran Otonom antara lain:

1. Pemungutan sumber-sumber pendapatan daerah

2. Penyelenggaraan pengurusan, pertanggungjawaban dan pengawasan keuangan daerah dan

3. Penetapan anggaran pendapatan dan belanja daerah (APBD)

Otonomi daerah pada prinsipnya memberi kewenangan kepada daerah untuk mengurus dan mengatur semua urusan pemerintah dengan membuat kebijakan daerah untuk memberikan pelayanan, peningkatan peran serta, prakarsa dan pemberdayaan masyarakat demi terwujudnya kesejahteraan masyarakat ( Halim,2007).

Landasan pelaksanaan desentralisasi fiskal yaitu UU No. 22 tahun 1999 jo UU No. 32 tahun 2004, UU No. 33 tahun 2004 tentang Perimbangan KeuanganantaraPemerintahPusatdanPemerintah 
Daerah . Pemerintah daerah diberi kewenangan mengurus dan mengatur urusan rumah tangganya , menggali potensi daerah, hak mendapatkan bagi hasil sumber-sumber daya nasional yang berada di daerah dan dana perimbangan lainnya.

Menurut Musgrave dan Musgrave ( Halim ,2007) menyatakan bahwa kebijakan fiskal mempunyai tiga fungsi yaitu:

1. Alokasi

2. Distribusi

3. Stabilisasi

Fungsi alokasi adalah proses yang sumber daya (resources) nasional digunakan untuk barang privat dan barang public untuk mengatasi kegagalan pasar. Fungsi distribusi adalah membagi pendapatan pemerintah kepada rakyat. Fungsi stabilisasi merupakan alat kebijakan makro pemerintah

Desentralisasi (pelimpahan wewenang dan tanggung jawab) di bidang administrasi dan politik, dilanjutkan dengan perimbangan keuangan antara pusat dan daerah merupakan perwujudan dari otonomi daerah.

Menurut UU N0. 33 Tahun 2004, Sumbersumber keuangan Daerah meliputi:

1. Pendapatan Asli Daerah (PAD)

2. Dana Perimbangan

3. Pinjaman Daerah dan

4. Lain-lain Pendapatan yang sah (hibah dan dana darurat)

Empat komponen penyusun PAD adalah:

1. Pajak Daerah

2. Retribusi Daerah

3. Hasil perusahaan milik daerah

4. Lain-lain pendapatan yang sah

Suatu daerah mampu melaksanakan otonomi (Halim ,2001) adalah :

1. Mempunyai kewenangan dan kemampuan mencari sumber pendapatan, mengatur dan menggunakan hasil pendapatan untuk membiayai keperluan berjalannya pemerintahan.
2. Ketergantungan keuangan pada bantuan pemerintah pusat seminimal mungkin

3. PAD merukan unsur utama Yang harus di gali pemerintah daerah untuk menunjukkan otonomi daerah yang disandang suatu daerah.

Kemampuan daerah dalam menjalankan otonomi daerah, salah satunya dapat diukur dengan kinerja keuang daerah yaitu menggunakan derajat desentralisasi fiskal antara pemerintah pusat dan daerah menurut Musgrave dan Musgrave, (Halim,2002 ) :

1. Pendapatan Asli Daerah (PAD)

Total Penerimaan Daerah (TPD)

2. Bagi Hasil Pajak/Bukan Pajak (BHPBP)

Total Penerimaan Daerah

3. Sumbangan dari Pusat (Sum)

Total Penerimaan Daerah

Kinerja keuangan daerah dapat pula di lihat dengan menggunakan derajat kemandirian daerah, yaitu mengukur kemampuan penerimaan yang berasal dari daerah dalam memenuhi kebutuhan daerah (Halim ,2007):

4. Pendapatan Asli Daerah (PAD)

Total Pengeluaran Daerah (TKD)

5. Pendapatan Asli Daerah (PAD)

Pengeluaran Rutin

6. $\mathrm{PAD}+\mathrm{BHPBP}$

Total Penerimaan Daerah (TPD) 
7. $\mathrm{PAD}+\mathrm{BHPBP}$

Total Pengeluran Daerah (TKD)

Suatu daerah mempunyai kemandirian dalam pembiayaan pengeluaran daerah tinggi ditunjukkan makin tingginnya derajat desentalisasi fiskal. Dengan kata lain daerah semakin mampu membiayai kebutuhan daerah tersebut, makin rendahnya ketergantungan terhadap bantuan pemerintah pusat.

\section{Hipotesis}

Otonomi daerah terutama dalam bidang keuangan Daerah dapat menunjukkan tingkat kemandirian daerah atau tingkat ketergantungan daerah terhadap bantuan pemerintah pusat dengan menganalisa peran Pendapatan asli Daerah dan Bagi Hasil Pajak/Bukan Pajak terhadap Total Penerimaan Daerah dan Total Pengeluaran Daerah.

Tingkat desentralisasi fiskal dan tingkat kemandirian daerah Kotamadya Metro dan Kabupaten Lampung Timur menunjukkan kemampuan daerah dalam mencari pendapatan untuk membiayai pengeluaran daerah. Makin besar derajat desentralisasi fiskal dan derajat kemandirian daerah menunjukkan makin besar kemampuan daerah dalam memenuhi kebutuhan daerah dan makin rendah ketergantungan terhadap pemerintah pusat.

\section{METODE PENELITIAN}

Objek dalam penelitian ini adalah Pendapatan Asli Daerah (PAD), Bagi Hasil Pajak dan Bukan Pajak (BHPBP), Total Penerimaan Daerah (TPD) dan Total Pengeluaran daerah (TPD). Penelitian ini bertujuan untuk menghitung derajat desentralisasi fiskal dan derajat kemandirian daerah.
Teknik pengumpulan data adalah studi dokumen Kotamadya Metro dan Kabupaten Lampung Timur kurun waktu tqhun 2005 sampai dengan tahun 2010.

Penghitungan derajat desentralisasi fiskal dengan rumus :

1. Pendapatan Asli Daerah (PAD)

Total Penerimaan Daerah (TPD)

2. Bagi Hasil Pajak/Bukan Pajak (BHPBP)

Total Penerimaan Daerah

3. Sumbangan dari Pusat (Sum)

Total Penerimaan Daerah

Pengukuran derajat kemandirian dengan persamaan:

1. Pendapatan Asli Daerah (PAD)

Total Pengeluaran Daerah (TKD)

2. $\mathrm{PAD}+\mathrm{BHPBP}$

Total Penerimaan Daerah (TPD)

3. $\mathrm{PAD}+\mathrm{BHPBP}$

Total Pengeluran Daerah (TKD)

\section{HASIL PENELITIAN DAN PEMBAHASAN}

\section{Paparan Kotamadya Metro}

Berdasar Peraturan Peralihan UUD 1945 pasal 2, Kota Metro menjadi Kabupaten yang sebelumnya hanya sebagai kota kecamatan. Makin berkembangnya potensi Metro, sebagai puat 
perdagangan, pendidikan, kebudayaan dan pusat pemerintahan Kotatif Metro berubah status menjadi Kota Madya Metro.

Daerah Otonom resmi di sandang Metro tanggal 27 April 1999 di Jakarta, berdasar UndangUndang Nomor 12 Tahun 1999, tanggal 20 April 1999. Setelah Resmi menjadi daerah Otonom Metro dibagi menjadi 2 kecamatan yaitu:

1. Kecamatan Metro Raya , terdiri dari:
1.1. Kelurahan Metro
1.2. Kelurahan Ganjaragung
1.3. Kelurahan Yosodadi
1.4. Kelurahan Hadimulyo
1.5. Desa Banjarsari
1.6. Desa Purwosari
1.7. Desa Karangrejo

2. Kecamatan Bantul

2.1. Kelurahan Mulyojati

2.2. Kelurahan Tejosari

2.3. Desa Margorejo

2.4. Desa Rejomulyo

2.5. Desa Sumbersari

Wilayah Metro dimekarkan berdasarkan Peraturan Daerah Kota Metro Nomor 25 Tahun 2000 tentang Pemekaran Kelurahan dan Kecamatan di Kota Metro, dari 2 kecamatan menjadi 5 kecamatan.

Geografi

Secara geografi, Metro terletak pada $105^{\circ} 17^{\prime}$ - $105^{\circ} 19^{\prime}$ BT dan $5^{\circ} 6^{\prime}$ - 5 $5^{\circ}$ ' LS, mempunyai batas-batas wilayah sebagai berikut:

1. Utara, berbatasan dengan Kabupaten Lampung Tengah dan Kabupaten Lampung Timur

2. Selatan, berbatasan dengan Kabupaten Lampung Timur

3. Timur, Berbatasan dengan Kabupaten Lampung Timur

4. Barat, berbatasan dengan Kabupaten Lampung Tengah

Luas wilayah Metro 6,874 Ha, terbagi dalam 5 kecamatan meliputi 22 kecamatan.

\section{Pemerintahan}

Kota Metro sebagai Kotamadya, dipimpin oleh seorang Walikota yaitu Bapak Lukman Hakim yang memimpin 5 kecamatan dengan 22 kelurahan, tahun 2010 jumlah RW dan RT masingmasing 212 dan 792.

Dalam pelaksanaan tugas legeslatif walikota bersama dengan DPRD yang beranggota 24 orang, pada periode 2009-2014 diketuai oleh Bapak Drs Sudarsono.

\section{Populasi dan Tenaga Kerja}

Tahun 2010, Kota Metro mempunyai penduduk sebesar 145.471 jiwa, tersebar dalam 5 kecamatan dan 22 kelurahan. Kota Metro dengan luas wilayah $68,74 \mathrm{~km}^{2}$, maka kepadatan penduduknya adalah $2.116 \mathrm{jiwa} / \mathrm{km}^{2}$.

Sex ratio Kota Metro adalah 100,80 yang berarti jumlah penduduk berjenis kelamin laki-laki dibanding penduduk perempuan 100,08 atau penduduk laki-laki $0.8 \%$ lebih banyak dari penduduk perempuan.

Angkatan kerja Kota Metro tahun 2010 $56,94 \%$, sedang tingkat pengangguran 7,09\%. Pasar Kerja di Kota Metro didominasi sektor perdagangan besar, eceran, rumah makan dan Hotel pada tahun 2010, sebesar 32,341\% dan diikuti jasa kemasyarakatan 32,339\%.

\section{Analisa Data Derajat Desentralisasi Fiskal Kotamadya Metro}

Tabel 1

PAD, TPD, Desentralisasi Fiskal kota Metro

Tahun 2008-2010

\begin{tabular}{|c|c|c|c|}
\hline Tahun & PAD & TPD & $\begin{array}{c}\text { Derajat } \\
\text { Desentralisasi } \\
\text { Fiskal }\end{array}$ \\
\hline 2005 & $12,889,125,368.05$ & $197,783,872,704.05$ & 0.065 \\
\hline 2006 & $17,543,354,677.91$ & $271,454,596,290.91$ & 0.065 \\
\hline 2007 & $17,045,445,278.00$ & $290,835,876,457.00$ & 0.059 \\
\hline 2008 & $19,980,632,952.26$ & $323,080,805,568.53$ & 0.062 \\
\hline 2009 & $21,060,409,868.49$ & $392,270,848,633.09$ & 0.054 \\
\hline 2010 & $27,345,197,826.11$ & $426,500,140,797.82$ & 0.064 \\
\hline
\end{tabular}

Sumber: Kota Metro Dalam Angka tahun 2005, 2006,

2008,2009,2010, Lembaran Daerah Kota Metro tahun 2007 
Dari Tabel 1. dapat dianalisa bahwa Derajat desentralisasi fiskal Kotamadya Metro mulai tahun 2005 sampai 2010, dihitung dari PAD dibanding TPD berturut-turut $6.5 \%, 6.5 \%, 5.9 \%$, $6.2 \%, 5.4 \%$ dan $6.4 \%$. Peran PAD dalam menyusun TPD rata-rata $6.2 \%$.

\section{Tabel 2}

Bagi Hasil pajak/Bukan Pajak, TPD, Derajat Desentralisasi Fiskal

\section{kota Metro Tahun 2004-2008}

\begin{tabular}{|c|c|c|c|}
\hline Tahun & $\begin{array}{c}\text { Bagi Hasil Pajak / } \\
\text { Bukan Pajak } \\
\text { (BHPBP) }\end{array}$ & TPD & $\begin{array}{c}\text { Derajat } \\
\text { Desentralisasi } \\
\text { Fiskal }\end{array}$ \\
\hline 2005 & $38,264,186,404.00$ & $197,783,872,704.05$ & 0.19 \\
\hline 2006 & $40,832,410,552.00$ & $271,454,596,290.91$ & 0.15 \\
\hline 2007 & $34,522,531,179.00$ & $290,835,876,457.00$ & 0.12 \\
\hline 2008 & $45,981,093,106.00$ & $323,080,805,568.53$ & 0.14 \\
\hline 2009 & $30,858,830,861.00$ & $392,270,848,633.09$ & 0.08 \\
\hline 2010 & $43,025,912,268.00$ & $426,500,140,797.82$ & 0.10 \\
\hline
\end{tabular}

Sumber: Kota Metro Dalam Angka tahun 2005, 2006, 2008,2009,2010, Lembaran Daerah Kota Metro tahun 2007, diolah.

Tabel 2 menunjukkan derajat desentralisasi fiskal kotamadya Metro dari tahun 2005 sampai dengan tahun 2010 diukur dari perbandingan anta Bagi hasil Pajak/Bukan Pajak terhadap TPD adalah 0.19, 0.15, 0.12, 0.14, 0.08, 0.10, atau peran Bagi hasil Pajak/Bukan Pajak dalam menyusun TPD rata-rata 0,13 .

Tabel 3

Tabel Pendapatan Asli Daerah PAD dan Total Pengeluaran Daerah (TKD), Derajat Kemandirian Daerah Kota Metro tahun 2008-2010

\begin{tabular}{|c|c|c|c|}
\hline Tahun & PAD & TKD & $\begin{array}{c}\text { Derajat } \\
\text { Kemandirian } \\
\text { Daerah }\end{array}$ \\
\hline 2005 & $12,889,125,368.05$ & $182,352,981,354.00$ & 0.07 \\
\hline 2006 & $17,543,354,677.91$ & $258,618,598,173.90$ & 0.07 \\
\hline 2007 & $17,045,445,278.00$ & $322,518,576,457.00$ & 0.05 \\
\hline 2008 & $19,980,632,952.26$ & $340,395,643,274.00$ & 0.06 \\
\hline 2009 & $21,060,409,868.49$ & $371,089,472,037.00$ & 0.06 \\
\hline 2010 & $27,345,197,826.11$ & $429,390,821,122.00$ & 0.06 \\
\hline
\end{tabular}

Sumber: Kota Metro Dalam Angka tahun 2005, 2006, 2008,2009,2010, Lembaran Daerah Kota Metro tahun 2007, diolah.
Pada Tabel 3 derajat kemandirian daerah Kotamadya Metro tahun 2005 sampai dengan 2010 dihitung dari perbandingan PAD terhadap TKD atau peran PAD dalam membiayai TKD adalah $0.07,0.07,0.05,0.06,0.06,0.06$, atau rata-rata $6 \%$.

\section{Tabel 4}

Pendapatan Asli Daerah (PAD), Bagi Hasil Pajak/Bukan Pajak (BHPBP), Total Penerimaan Daerah (TPD), Derajat Kemandirian Daerah Kota Metro tahun 2008-2010

\begin{tabular}{|c|c|c|c|}
\hline Tahun & PAD + BHPBP & TPD & $\begin{array}{c}\text { Derajat } \\
\text { Kemandirian } \\
\text { Daerah }\end{array}$ \\
\hline 2005 & $51,153,311,772.06$ & $197,783,872,704.05$ & 0.26 \\
\hline 2006 & $58,375,764,942.00$ & $271,454,596,290.91$ & 0.22 \\
\hline 2007 & $51,567,976,457.00$ & $290,835,876,457.00$ & 0.18 \\
\hline 2008 & $65,961,726,058.26$ & $323,080,805,568.53$ & 0.20 \\
\hline 2009 & $51,919,240,729.49$ & $392,270,848,633.09$ & 0.13 \\
\hline 2010 & $70,371,110,094.11$ & $426,500,140,797.00$ & 0.17 \\
\hline
\end{tabular}

Sumber: Kota Metro Dalam Angka tahun 2005, 2006, 2008,2009,2010, Lembaran Daerah Kota Metro tahun 2007, diolah.

Tabel 4. Menunjukkan Derajat Kemandirian Daerah diukur dengan penjumlahan PAD dan BHPBP dibanding TPD mulai dari tahun 2005 sampai dengan tahun 2010 adalah $0.26,0.22$, $0.18,0.20,0.13,0.17$. Peran PAD bersama BHPBP dalam membentuk TPD rata-rata 19\%.

\section{Tabel 5}

Pendapatan Asli Daerah (PAD),Bagi Hasil Pajak/Bukan Pajak (BHPBP), Total

Pengeluaran Daerah (TKD), Derajat Kemandirian Daerah Kota Metro tahun 2008-2010

\begin{tabular}{|c|c|c|c|}
\hline Tahun & PAD + BHPBP & TKD & $\begin{array}{c}\text { Derajat } \\
\text { Kemandirian } \\
\text { Daerah }\end{array}$ \\
\hline 2005 & $51,153,311,772.06$ & $182,352,981,354.00$ & 0.28 \\
\hline 2006 & $58,375,764,942.00$ & $258,618,598,173.00$ & 0.23 \\
\hline 2007 & $51,567,976,457.00$ & $322,518,576,457.00$ & 0.16 \\
\hline 2008 & $65,961,726,058.26$ & $340,395,643,274.00$ & 0.19 \\
\hline 2009 & $51,919,240,729.49$ & $371,089,472,037.00$ & 0.14 \\
\hline 2010 & $70,371,110,094.11$ & $429,390,821,122.00$ & 0.16 \\
\hline
\end{tabular}

Sumber: Kota Metro Dalam Angka tahun 2005, 2006, 2008,2009,2010, Lembaran Daerah Kota Metro tahun 2007, diolah. 
Derajat Kmandirian Kotamadya Metro dalam Tabel 5 mulai dari tahun 2005 sampai dengan tahun 2010 yang dihitung dari penjumlahan antara PAD dan BHPBP dibanding TKD atau peran bersama PAD dan BHPBP dalam membiayai TKD adalah $0.28,0.23,0.16,0.19,0.14,0.16$ dan rata-rata adalah 0.19 atau $19 \%$.

\section{Letak Geografis}

Secara geografi, Lampung Timur terletak pada $4^{\circ} .37^{\prime}-5^{\circ} .37^{\prime}$ Lintang Selatan dan, $105^{\circ} 15^{\prime}$ - 106 $20^{\prime}$. Luas wilayah Lampung Timur 5,325.03 $\mathrm{Km}^{2}$, mempunyai batas-batas wilayah sebagai berikut:

1. Sebelah Utara : Kabupaten Lampung Tengah

2. Sebelah Timur: Laut Jawa

3. Sebelah Selatan: Kabupaten Lampung Selatan

4. Sebelah Barat : Kabupaten Lampung Tengah

\section{Pemerintahan}

Kabupaten Lampung Timur, dipimpin oleh seorang Bupati yaitu Bapak Erwin Arifin yang memimpin 24 kecamatan

Dalam pelaksanaan tugas legeslatif BUPATI bersama dengan DPRD di ketuai oleh Bapak Ali Johan Arif, dengan jumlah anggota DPRD sebanyak 45.

\section{Populasi dan Tenaga Kerja}

Tahun 2010, Lampung Timur mempunyai penduduk sebesar 951.639 jiwa, tersebar dalam 24 kecamatan, 257 Desa dan. dengan kepadatan penduduknya rata-rata $179 \mathrm{jiwa} / \mathrm{km}^{2}$.

Sex ratio Lampung Timur tahun 2010 adalah 105.55 yang berarti jumlah penduduk berjenis kelamin laki-laki dibanding penduduk perempuan 105,55 atau penduduk laki-laki $0.5 \%$ lebih banyak dari penduduk perempuan.
Angkatan kerja Lampung Timur tahun 2010, 497.456, sedang bekerja 476.17, persentase terhadap Angkatan kerja 95,72\%, sedang mencari kerja 21.277.

Analisa Data Derajat Desentralisasi Fiskal Kabupaten Lampung Timur

Tabel 6

PAD, TPD, Desentralisasi Fiskal Kabupaten

Lampung Timur Tahun 2005-2010

\begin{tabular}{|c|c|c|c|}
\hline Tahun & PAD & TPD & $\begin{array}{c}\text { Derajat } \\
\text { Desentralisasi } \\
\text { Fiskal }\end{array}$ \\
\hline 2005 & $7,499,519,000.00$ & $449,235,268,000.00$ & 0.02 \\
\hline 2006 & $16,791,822,547.00$ & $610,257,849,738.00$ & 0.03 \\
\hline 2007 & $30,311,592,000.00$ & $707,120,257,000.00$ & 0.04 \\
\hline 2008 & $26,645,226,534.00$ & $755,523,896,869.00$ & 0.04 \\
\hline 2009 & $20,985,633,360.00$ & $993,531,787,082.00$ & 0.02 \\
\hline 2010 & $20,669,866,389.00$ & $1,003,742,155,881.00$ & 0.02 \\
\hline
\end{tabular}

Sumber : Lampung Timur Dalam Angka, BPS , tahun

$$
\text { 2005-2010, diolah }
$$

Derajat desentralisasi fiskal Kabupaten Lampung Timur, tahun 2005-2010 berturut-turut : $2 \%, 3 \%, 4 \%, 4 \%, 2 \%, 2 \%$, menunjukkan peran PAD di banding keseluruhan penerimaan daerah dibawah $5 \%$ artinya masih cukup rendah . Terjadi peningkatan derajat desentralisasi fiskal kurun 4 tahun yaitu tahun 2005-2007, namun menurun ditahun 2008, terakhir tahun 2009 tetap sama pada tahun 2008.

Secara Umum besar derajat desentralisasi fiskal tersebut dipengaruhi oleh :TPD mulai tahun 2005 sampai dengan tahun 2010 terus mengalami peningkatan, sedangkan PAD meningkat di 3 tahun pertama yaitu 2005,2006,2007, namun tahun 2008,2009,2010 mengalami penurunan. 
Tabel 7

Bagi Hasil pajak/Bukan Pajak, TPD, Derajat Desentralisasi Fiskal Kabupaten Lampung Timur tahun 2005-2010

\begin{tabular}{|c|c|c|c|}
\hline Tahun & $\begin{array}{c}\text { Bagi Hasil Pajak } \\
\text { / Bukan Pajak } \\
\text { (BHPBP) }\end{array}$ & TPD & $\begin{array}{c}\text { Derajat } \\
\text { Desen- } \\
\text { tralisasi } \\
\text { Fiskal }\end{array}$ \\
\hline 2005 & $91,728,762,000.00$ & $449,235,268,000.00$ & 0.20 \\
\hline 2006 & $111,395,893,889.00$ & $610,257,849,738.00$ & 0.18 \\
\hline 2007 & $105,234,623,000.00$ & $707,120,257,000.00$ & 0.15 \\
\hline 2008 & $130,017,084,535.00$ & $755,523,896,869.00$ & 0.17 \\
\hline 2009 & $99,661,375,114.00$ & $993,531,787,082.00$ & 0.10 \\
\hline 2010 & $144,600,259,727.00$ & $1,003,742,155,881.00$ & 0.14 \\
\hline
\end{tabular}

Sumber : Lampung Timur Dalam Angka 20052010 ,

Desentralisasi fiskal yang dihitung dari $\mathrm{BH}-$ PBP/TPD menghasilkan angka 20\%,18\%,15\%, $17 \%, 10 \%$ dan $14, \%$. Menunjukkan BHPBP lebih tinggi sebagai komponen penyusun TPD dibanding PAD.

Tabel 8.

Tabel Pendapatan Asli Daerah PAD dan Total Pengeluaran Daerah (TKD), Derajat Kemandirian Daerah Kabupaten Lampung Timur tahun 2005-2010

\begin{tabular}{|c|c|c|c|}
\hline Tahun & PAD & TKD & $\begin{array}{c}\text { Derajat } \\
\text { Keman- } \\
\text { dirian } \\
\text { Daerah }\end{array}$ \\
\hline 2005 & $7,499,519,000.00$ & $394,217,431,000.00$ & 0.02 \\
\hline 2006 & $16,791,822,547.00$ & $883,615,727,012.78$ & 0.02 \\
\hline 2007 & $30,311,592,000.00$ & $705,928,189,000.00$ & 0.04 \\
\hline 2008 & $26,645,226,534.00$ & $695,722,623,275.10$ & 0.04 \\
\hline 2009 & $20,985,633,360.00$ & $754,009,465,851.00$ & 0.03 \\
\hline 2010 & $20,669,866,389.00$ & $754,009,465,851.00$ & 0.03 \\
\hline
\end{tabular}

Sumber: Lampung Timur Dalam Angka 2005-2010, diolah

Dari data Tabel 3 , Derajat kemandirian daerah Kabupaten Lampung Timur tahun 2005-2010, dihitung dari peran PAD dalam pembiayaan pengeluaran total daerah adalah $2 \%, 2 \%, 4 \%, 4 \%$, $3 \%, 3 \%$, masih cukup rendah yaitu dibawah $3 \%$. PAD meningkat dari tahun 2005-2007, mulai tahun 2008-2010 mengalami penurunan. TKD juga mengalami kenaikkan tahun2005-2007, menurun di tahun 2007 tetap untuk tahun 2009 dan 2010.
Tabel 9

Pendapatan Asli Daerah (PAD),Bagi Hasil Pajak/Bukan Pajak (BHPBP), Total Penerimaan Daerah (TPD), Derajat Kemandirian Daerah Kabupaten Lampung Timur tahun 2005-2010

\begin{tabular}{|c|c|c|c|}
\hline Tahun & PAD+BPPBP & TPD & $\begin{array}{c}\text { Derajat } \\
\text { Keman- } \\
\text { dirian } \\
\text { Daerah }\end{array}$ \\
\hline 2005 & $99,228,281,000.00$ & $449,235,268,000.00$ & 0.22 \\
\hline 2006 & $128,187,716,436.00$ & $610,257,849,738.00$ & 0.21 \\
\hline 2007 & $135,546,215,000.00$ & $707,120,257,000.00$ & 0.20 \\
\hline 2008 & $156,662,311,069.00$ & $755,523,896,869.00$ & 0.20 \\
\hline 2009 & $120,647,008,474.00$ & $993,531,787,082.00$ & 0.12 \\
\hline 2010 & $165,270,126,116.00$ & $1,003,742,155,881.00$ & 0.17 \\
\hline
\end{tabular}

Sumber : Lampung Timur Dalam Angka tahun 2005-2010, diolah

Tingkat kemandirian daerah dalam Tabel 5 dari tahun 2005-2010 sebesar 22\%, 21\%, 20\%, $20 \%, 12 \%$ dan $17 \%$, menunjukkan peran PAD dan BHPBP dibanding TPD. Besar TDP selalu meningkat, demikian pula PAD+BHPBP mengalami peningkatan kecuali di tahun 2009 mengalami penurunan.

\begin{tabular}{|c|c|c|c|}
\hline \\
\hline $\begin{array}{r}P \\
\text { Has } \\
P \\
\text { Kem }\end{array}$ & $\begin{array}{l}\text { dapatan Asli } \\
\text { Pajak/Bukan } \\
\text { geluaran Dae } \\
\text { dirian Daeral } \\
\text { Timur tahı }\end{array}$ & $\begin{array}{l}\text { aerah (PAD),B } \\
\text { ajak (BHPBP), } \\
\text { ah (TKD), Der: } \\
\text { Kabupaten La } \\
\text { n } 2005-2010\end{array}$ & $\begin{array}{l}\text { gi } \\
\text { Total } \\
\text { at } \\
\text { eung }\end{array}$ \\
\hline Tahun & PAD + BHPBP & TKD & $\begin{array}{c}\text { Derajat } \\
\text { Keman- } \\
\text { dirian } \\
\text { Daerah }\end{array}$ \\
\hline 2005 & $99,228,281,000.00$ & $394,217,431,000.00$ & 0.25 \\
\hline 2006 & $128,187,716,436.00$ & $883,615,727,012.78$ & 0.15 \\
\hline 2007 & $135,546,215,000.00$ & $705,928,189,000.00$ & 0.19 \\
\hline 2008 & $156,662,311,069.00$ & $695,722,623,275.10$ & 0.23 \\
\hline 2009 & $120,647,008,474.00$ & $754,009,465,851.00$ & 0.16 \\
\hline 2010 & $165,270,126,116.00$ & $754,009,465,851.00$ & 0.22 \\
\hline
\end{tabular}

Sumber : Lampung Timur Dalam Angka 2005-2010, diolah 
Derajat kemandirian daerah kabupaten Lampung Timur bila diukur berdasar perbandingan Pendapatan Asli Daerah ditambah Bagi Hasil Pajak /Bukan Pajak terhadap Total pengeluaran daerah cukup rendah dari tahun $2005-2010$ adalah $25 \%, 15 \%, 19 \%, 23 \%, 16 \%$ dan 22\% masih dibawah $30 \%$. Peran PAD dan BHPBP dalam membiayai pengeluaran daerah kurang dari $30 \%$.

\section{KESIMPULAN DAN SARAN}

Hasil analisis menunjukkan bahwa kotamadya Metro mempunyai derajat desentralisasi fiskal dan derajat kemandirian daerah masih cukup rendah. Kotamadya Metro mempunyai ketergantungan yang tinggi kepada pemerintah pusat dalam pembiayaan pengeluarannya.

Kabupaten Lampung Timur mempunyai derajat desentralisasi fiskal dan derajat kemandirian daerah rendah, menunjukkan masih tinggi ketergantungan terhadap pemerintah pusat dalam hal pembiayaan keperluan daerah.

Otonomi daerah yang makin tinggi akan terwujud dengan lebih baik bila didukung oleh kemampuan daerah sendiri dalam membiayai keperluan operasionalnya. Bantuan Pusat seharusnya makin mengecil perannnya dalam pembiayaan daerah. Perlu usaha lebih intensif bagi Kotamadya Metro dan Kabupaten Lampung Timur untuk menggali Pendapatan Asli Daerah, sebagai komponen utama pendapatan daerah untuk membiayai pengeluaran daerah.

\section{DAFTAR PUSTAKA}

Paul A. Samoelson, William D. Nordhaus 2002, Econimics. Seventeenth Edition, Singapore: Irwin McGrawHill.

Sadono Sukirno 2010, Makro Ekonomi Teori Pengantar, PT Raja Grafindo Persada, Jakarta

Suparmoko 1990, Keuangan Negara dalam Teori dan Praktek, Edisi 4, BPFE, Yogyakarta

Abdul Halim, Theresia Damayanti, 2007, Pengelolaan Keuangan Daerah, Edisi 2, UPP STIM YKPN, Yogyakarta. 